\title{
Measuring EXCESSIVE PRICING AS AN ABUSE OF DOMINANCE - AN ASSESSMENT OF THE CRITERIA USED IN THE HARMONY GOLD/ Mittal Steel complaint
}

Reena das Nair ${ }^{1}$

Competition Commission of South Africa

\begin{abstract}
The Competition Tribunal recently found Mittal Steel SA guilty of abusing its super-dominant position by charging excessive prices to the detriment of consumers of flat carbon steel products. This article assesses the economic tests to be used for excessive pricing in light of the case and reviews the lessons that can be learned from the evidence required for the different tests. It discusses issues related to using profitability as a test and points out problems and pitfalls in profitability measures.
\end{abstract}

JEL L41

\section{1}

\section{Introduction}

Section 8 (a) of the South African Competition Act (Act 89 of 1998 as amended) prohibits a dominant firm from charging an excessive price to the detriment of consumers. Under Chapter 1 , such a price is defined as one that bears no reasonable relation to the economic value of a good or service and one that is higher than this value. The Tribunal heard its first excessive pricing complaint in 2006, which was brought against Mittal Steel SA by mining companies Harmony Gold Mining and Durban Roodepoort Deep².

This article looks at the broad economic issues surrounding excessive pricing as an abuse of dominance in an industrial organisation framework. It seeks to draw key insights from the approaches taken by the parties and the Tribunal in the case against Mittal Steel SA to arrive at the appropriate and relevant tests to assess excessive pricing. It looks at the rationale behind Mittal's pricing behaviour, how it implemented the pricing system, and why this is indicative of the unilateral exertion of market power. Some of the tools available to assess excessive prices prescribed by international case law are evaluated and examples of how these were applied in the analysis of Mittal's domestic prices for flat steel products, including the difficulties and pitfalls of using these tools, are considered.

\section{2}

\section{The contrasting theoretical approaches to excessive pricing}

To assess excessive pricing as a contravention of the Competition Act and to identify the appropriate tests that can be used to show this, it is helpful to understand the different theoretical positions in the debate.

The structure-conduct-performance paradigm (SCP) or the Harvard ('structuralist') approach in industrial organisation posits that the performance of an industry is a function of the conduct of its market players, which in turn is a function of the industry's structure (Martin, 1993: 3). Under this paradigm, firms in highly concentrated industries facing limited or no competition can charge prices that are well above those in less concentrated markets. In other words, structure allows for conduct and determines outcomes such as pricing levels.

By comparison, the efficiency paradigm, or the Chicago School approach, maintains that the most efficient and low cost firms gain 
market share and earn higher profits due to this superiority (Demsetz, 1973a, 1973b and 1974; see Leach, 1992: 143). As a consequence, concentration increases as these firms gain market share due to their competitive edge over others. This therefore is the exact reverse causality to that of the structuralists, that is, performance and competitive conduct leads to a structure that may be concentrated. Prices which may appear high relative to costs and are being set by a dominant firm are, in this interpretation, the reward to a low cost, efficient firm. While this perspective suggests competition authorities should not generally be concerned with pricing that may appear to be excessive, it ultimately still rests on the nature of the market and firm conduct in question.

While the rift between the two schools of thought amongst academics is obvious in South Africa (as discussed in Reekie, 1999: 269), the framework used by the South African competition authorities in the past has broadly been the SCP framework (Theron, 2001: 620).

An important concern is around the ease of entry. If we emphasise new entry as the source of competitive discipline then high prices are a means of rewarding firms for risk-taking and innovation, and provide an incentive to develop superior products and services. It is therefore accepted that under normal competitive conditions, with low barriers to entry and contestable markets, "excessive" prices pose little concern as they are the stimulus for new entry to occur. However, under high barriers to entry and conditions of imperfect competition, there may not be sufficient rivalry to undermine supra-competitive prices over time.

Indeed, certain international authorities recognise that excessive prices are a concern in circumstances where entry barriers are high resulting in diminished effective rivalry (Monti, 2006: 7). The EC competition authorities believe that there are significant and long-term market failures that prevent the market from working effectively and that imperfect competition and high barriers to entry are widespread. This is especially so in the case of monopolies that attained entrenched dominant positions through current or past state support or legal rights and which operate in incontestable markets with little or no effective rivalry. Under such conditions, it is possible that firms charge prices that are above what is considered a product's economic value. The EC directly prohibits imposing "unfair purchase or selling prices" on customers and asserts that there is some fair price that serves to redistribute wealth and power (Evans \& Padilla, 2005: 98). In the EC, and in South Africa, every dominant firm has a special obligation not to set excessive prices, regardless of how it attained its dominance. A firm is considered dominant in South African law if it can control prices, or exclude competition, or behave to an appreciable extent independently of its competitors, customers or suppliers. However, US competition law does not oppose monopoly pricing per se and takes the Chicago view that markets work best untampered by regulators and that markets are generally highly contestable with high prices encouraging new entry (Gal, 2004: 345, 346).

Under the South African Act, the critical question is framed in terms of the price relative to the "economic value" of the good or service, with economic value left to the authorities to determine. Economic theory would suggest that a perfectly competitive price in a static framework is one that approximates marginal costs. In such instances, markets outcomes are efficient and welfare to society is maximised, thus the perfectly competitive price could be taken as representing "economic value". Under this framework, any deviation from this optimal situation is welfare-reducing. However, in reality the conditions for perfect competition rarely hold, making it difficult to assess pricing in terms of deviations from this benchmark. Arriving at the appropriate competitive benchmark is especially difficult in dynamic industries which are highly innovative and make large investments including in Research and Development (R\&D) (Evans \& Padilla, 2005: 101).

This implies that appropriate tests for excessive pricing, and the likelihood of errors of overenforcement (type 1 errors) against underenforcement (type 2 errors), have to be evaluated in the context of the industries in question. For example, simple price-cost margin tests could lead to over-enforcement where they have a chilling effect on investment incentives, as potential 
investors fear prosecution if their investments serve to greatly reduce cost of production. This type of error is more likely in dynamic industries where firms compete for the sale of new or improved products and services, and where entry barriers are low. The cost to society is the loss to consumers as introduction of a valuable good or service is discouraged. Type 2 errors result in supra-competitive prices persisting, which lead to loss of consumer welfare either by consumers paying more than the competitive price or by being excluded altogether.

Motta and de Streel (2006: 91) explain that excessive prices may be an exploitative abuse of market power or an exclusionary abuse aimed at strengthening or maintaining market power of the dominant firm. Similar to Evans and Padilla, Motta and de Streel caution against anti-trust intervention in cases of excessive prices except under very specific conditions of high and non-transitory barriers to entry leading to a super-dominant position, and when this super-dominant position is due to current or past exclusive rights or un-condemned past anticompetitive practices.

After the industry conditions have been taken into account, several different methods could be used to assess excessive pricing. These methods include comparing prices to costs and various other benchmarks, such as prices in more competitive markets, or assessing the profitability of the product in question. Further, the different methods can be useful in directing competition authorities to find the most efficient remedy. The problems and pitfalls in the different approaches are discussed below and illustrated using the case study.

In the case brought by Harmony and DRD of excessive pricing by Mittal Steel SA, the focus was on whether the conduct was consistent with the unilateral exertion of durable market power as compared with what would be expected under effective competition (rather than perfect competition). Under effective competitive rivalry prices would be expected to be reflective of factors including production costs, and hence, of economic value.

Given that Mittal faces no direct effective rivals locally, the complainants scrutinised the pricing system in place that leads to the prices charged to most local customers and compared this against pricing in the few markets that Mittal faces some (although limited) competitive discipline. As in international excessive pricing cases, the complainants utilised a range of benchmarks, as discussed below, to show what prices would tend to under some level of effective competition.

The defendant's main approach to the relevant test for excessive pricing was a profitability analysis. The Tribunal rejected both profitability and a cost-based approach to measuring economic value, and instead emphasised the structural conditions coupled with ancillary conduct that prevents the effective functioning of the market ${ }^{3}$.

This meant that the various sides laid differing emphasis on structure, conduct and performance, as we now discuss in more detail.

\section{3}

\section{The different tests for assessing excessive pricing - a case study of the South African flat steel market}

In drawing on the case study, I start with structural features, especially barriers to entry and barriers to importing. The conduct is then examined in some detail before assessing the merits of profitability as a measure of performance.

\subsection{Barriers to entry: Supply of flat steel to the South African market}

There is consensus that barriers to entry are an important starting point. If entry is relatively easy then market power cannot be sustained. In this case, there are significant non-transitory barriers to entry. In addition, the incumbent dominant firm in the South Africa flat steel industry, Mittal Steel SA (formerly Iscor), does not owe its position to superior efficiency, cost-savings or innovation but to previous state ownership and continued state support postprivatisation.

\section{- Extensive state support}

The basis for a company's dominant position and the relevance of state support and 
protection in this regard is a very important consideration if the excessive pricing provision is not to risk wrongly penalising firms who have merely been successful in competing on their merits (Fingleton, 2006: 65). For example, Motta and de Streel caution that "the Commission should only intervene in cases of very strong dominance (confined to a monopoly or near monopoly) that are caused by past or current legal barriers" (Motta and de Streel, 2006: 124). This is reinforced by Evans and Padilla (2005: 100).

Mittal was a state-owned and operated entity. Even after it was privatised in 1989, Mittal continued to receive significant state support throughout the nineties. It received incentives through the General Export Incentive Scheme and through accelerated depreciation tax allowances. It also received support under the Regional Industrial Development Scheme (which became the Small and Medium Manufacturing Development Programme) as well as a tax write-off under the Strategic Investment Programme. The Industrial Development Corporation further provided financial assistance to Mittal. Such extensive state support post privatisation, although no longer in the form of a legal barrier, allowed Mittal, and not other steel-manufacturing firms to become the dominant player in the SA steel industry.

- Economies of scale

Given that steel production involves large economies of scale it is reasonable then to expect a concentrated market as minimum efficient scale is reached with only a few firms in the market. This is the case in the SA steel industry. Mittal is the dominant player in the flat steel market (of which hot rolled coil is a main product), producing around 80 per cent of flat steel in the local market (the flat steel industry's local sales in 2007 amounted to 2.8 million tonnes) $)^{5}$. Highveld Steel, as the only other local producer, accounts for the remainder, aside from small volumes of imports, and it also focuses on a particular product range.

\section{- High transport costs}

Imports are limited, given the high cost of transporting steel over large distances. Mittal finds itself in a naturally protected market. Large distances from international markets and rising shipping costs add a significant margin of transport costs onto a relatively low value-heavy weight product. Shipping and all associated transport costs could constitute more than 40 per cent of the cost of product imported into South Africa ${ }^{6}$. Prior to April 2006, there was also a 5 per cent duty on imported steel, which further raised the import cost. This duty has since been abolished. High transport and associated costs nonetheless significantly limit the competitiveness of steel imports.

- Input cost advantage

SA has numerous advantages in the production of steel and faces low input costs. The basic inputs needed are iron ore, electricity, coking coal, natural gas and labour. SA has abundant and good-quality iron-ore deposits, relatively cheap labour and cheap electricity costs, while only coking coal is imported. Mittal achieves significant absolute cost advantages for iron ore from being backwardly integrated with its source - Kumba. A long-term preferential agreement was struck at the time of Kumba's unbundling allowing Mittal access to very cheap iron ore at cost plus 3 per cent ${ }^{7}$.

Mittal also enjoys cost benefits in its electricity input which is required in the running of the electric arc furnaces. It secured a 25-year deal with Eskom for its electricity costs, with modest price increases. Research by the Commodity Research Unit (CRU), an international body that analyses steel markets globally showed that in 2002, Mittal's electricity costs were $\$ 0.013 / \mathrm{kWh}$ as compared to a world average of $\$ 0.045 / \mathrm{kWh}$. The cost of natural gas was $\$ 1.7 / \mathrm{GJ}$ compared to a world average $\$ 4.7 / \mathrm{GJ}$ in the same year ${ }^{8}$. Indeed, Mittal's Vanderbijlpark operating costs were $\$ 250 /$ tonne (which ranked 17th out of 158 plants worldwide in terms of ascending costs) while the total world weighted average was $\$ 325 /$ tonne $^{9}$. 
Mittal is backwardly integrated in the supply of its key inputs. These and other agreements help to maintain its market position and increase the barriers to entry for new entrants who are not able to secure such favourable terms. Mittal, in its annual results for the 12 months ended December 2004 presentation, highlights how its Vanderbijlpark and Saldanha operations are amongst the lowest operating cost producers of Hot-Rolled Coil (HRC) globally ${ }^{10}$.

\subsection{Assessing conduct in the determi- nation of excessive pricing: Mittal Steel SA's pricing of flat steel}

Conduct is at the heart of understanding a firm's pricing and its wider impact; merely being a dominant entity is clearly not sufficient to conclude that a firm's pricing is excessive. Its conduct in how it sets prices should be analysed to see whether this takes into account any rivalry or if the prices are unilaterally imposed onto customers. The outcome of this conduct should be assessed to see whether it has an anticompetitive effect.

Import parity pricing (IPP) was, until recently, the pricing mechanism employed by Mittal in its pricing of flat steel products. A range of costs are added to the free on board (Black Sea) price to arrive at an IPP for a given product specification for a given month ${ }^{11}$. These costs include shipment, transport, administration costs as well as a "hassle" factor (a non-price component that captures the hassle of shipping delays, delivery lags, etc.). This is compared to the list price given to Mittal's customers. After volume and settlement discounts are taken into account, the difference between the calculated hypothetical IPP and the local list price is credited/debited to/from the customer through an import parity discount/surcharge. It must be noted that this import price is a notional or hypothetical price and that the imports which such prices are based on do not physically come into South Africa. Below is a breakdown of how the IPP was calculated:

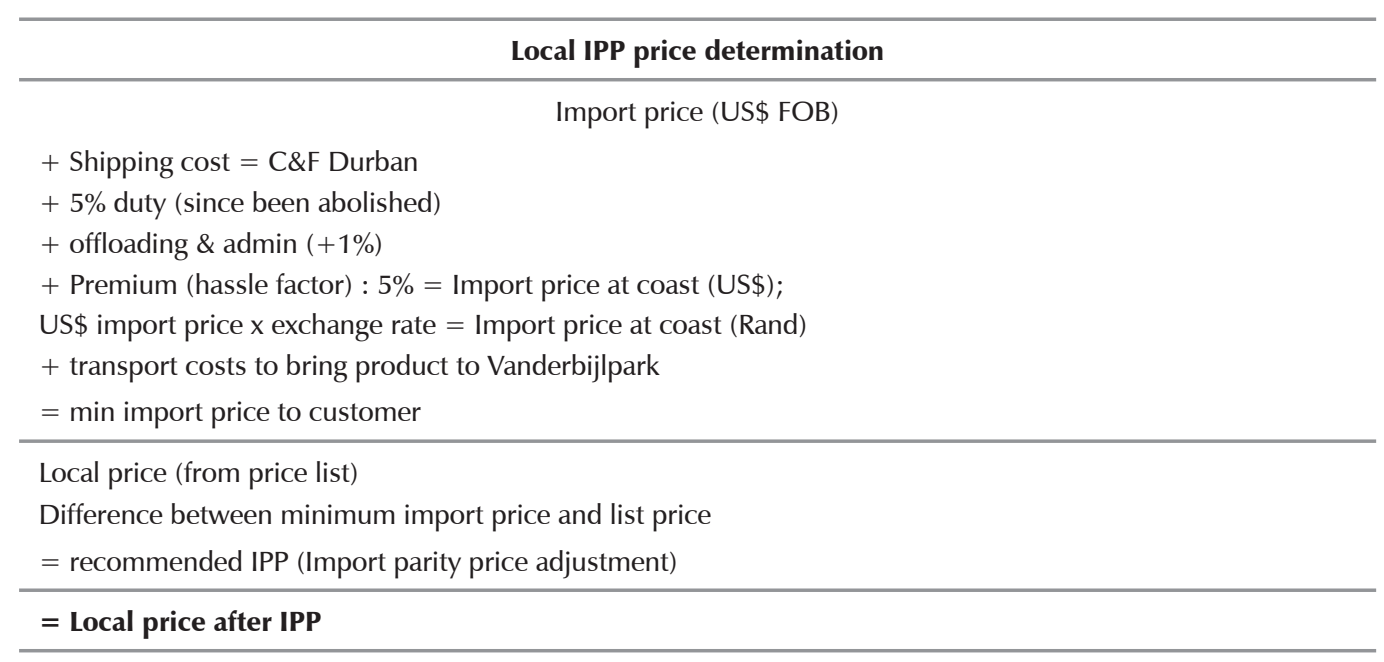

The point is not, however, that import parity pricing is excessive but that in the circumstances of this market and industry in South Africa it reflects the sustained unilateral exertion of market power. These circumstances are, first, that Mittal has several cost advantages in the production of flat steel locally as described earlier and a pricing practice like IPP is not in any way cost-related. Second, and related, is that such cost advantages allow Mittal (and South Africa) to be a large net-exporter of basic flat steel products. In 2007, the domestic market for flat steel products accounted for 2.8 million tonnes, while 1.4 million tonnes of flat steel produced locally were sold in the export market, of which most output can be attributed to $\mathrm{Mittal}^{12}$. In a net-exporting country of flat steel products, the competitive price should 
tend towards the export price of the product. The opportunity cost of not supplying product into the local market is to sell those units into the export market at the achievable export price. The export market is more competitive than the local market given numerous international players.

The attractiveness of lower than IPP prices to the producer is well illustrated by price-cost comparisons and differential prices charged by Mittal to identified groups of customers.

\section{Price-cost comparison}

An excessive price can be looked at as one that covers by a large margin, the dominant firm's costs plus a reasonable rate of return. Theoretically, an efficient firm in a competitive environment under static conditions with little innovation, prices at marginal cost. In reality however, a firm's marginal costs are difficult to calculate. Instead, average variable costs are typically used in competition issues (see for instance Office of Fair Trading (OFT), 2003) although these are also difficult to determine.

Another complicating factor in undertaking price-cost comparisons is the allocation of common costs in multi-product firms. These are costs that arise from two or more products being produced together ${ }^{13}$. While these costs vary with output to a certain extent, it is difficult to allocate them to a particular product (Whish, 2003: 689). Often it is the case that the competition authorities are concerned only about one particular product of the firm (one product is thought to be priced excessively).

Generally, using any cost figure of the dominant firm's costs might be misleading. The firm's costs may be high because of inefficiency and hence, a price over an inflated cost is not a true representation of the extent of excessive pricing. The firm in question may be inefficient due to managerial slack (X-inefficiency) or due to complacency from the lack of effective competition as a disciplining tool.

It is just as difficult to determine what the standard reasonable rate of return figures or margins over cost should be. In industries that engage in high levels of R\&D (e.g., pharmaceutical companies that develop new drugs) and those that have considerable intellectual property (e.g., software developers), there is little contention that such risk and innovation should be rewarded. Persistent high prices over costs in a prolonged period of time may sound alarm bells, but the effect may not necessarily be anti-competitive. It is when such high prices prevail over time and no new entry is witnessed that the situation may become a cause for concern (OFT, 2003: 6, 23, 34).

Purely comparing prices to a firm's marginal costs or other identified costs does not unambiguously provide an answer to what a competitive benchmark should be. In a recent decision involving the excessive pricing of prerace horseracing data ${ }^{14}$, the UK Appeal Court ruled that it was not correct to always equate the "economic value" of the product to the cost of producing the product plus a reasonable profit (that is, a price-cost analysis). The economic value of a product may be well above the cost of producing it if it encapsulates externalities or benefits (similar to the case of innovation and investment). In this case the Appeal Court felt that determining the competitive price by simply equating it to any justifiable allocation of cost of production and a reasonable rate of return failed to take into account the economic value of the pre-race horseracing data to the complainant and what it could make out of the data as a source of income.

Prices can also be compared across countries that have similar cost structures. In this case, when the prices in plants in different low-cost countries such as Taiwan and South Korea were compared with Mittal's prices (also a low cost producer), Mittal's margins were seen to be substantially higher ${ }^{15}$. The complainants noted the difficulty in undertaking robust international price-cost comparisons in that each country is faced with unique circumstances and domestic prices are often collected under very different conditions and assumptions. Drawing conclusions solely on such comparisons is therefore likely to be problematic.

Given the difficulty in undertaking accurate direct price-cost comparisons and the potential ambiguity of the results, price-cost assessments need to be viewed in a wider context of firm conduct. 


\section{Comparators that show what prices would tend to under effective competition}

The role of comparators in assessing excessive pricing is to identify the level to which prices would tend to under effectively competitive conditions. This then offers a benchmark to which the existing price can be compared ${ }^{16}$.

In this case the comparators themselves were indicators of conduct, with the prices being the result of specific arrangements consistent with the exertion of market power to differing degrees.

\section{a. Secondary export rebates}

Secondary export rebates are awarded to firms that buy steel from Mittal, add value to it and then export the value-added product. The rebate is only given after strict conditions are adhered to that show that Mittal's product was used as an input material, at least twenty per cent value was added to the steel and the value-added product was indeed exported. Between 2001 and 2004, a significant amount was given in the form of secondary export rebates.

Mittal itself explains that the price faced by local firms after they receive the secondary export rebates is close to the export price. As mentioned earlier, in a net-exporting country the competitive price would tend towards the export price given international competition for the product. The price received by these firms that export may be a more competitive price than those paid by the general population and hence is a useful comparator (although the limitations of using the export price as a comparator are explained later). This price is significantly lower than the IPP and was clearly revealed in the pipe and tube industry, one that benefits greatly from this class of rebate. Heavy earth-moving and construction machinery manufacturers and manufacturers of conveyor belts also receive such rebated steel prices for the products that they export.

b. Rebates for import-competing products In order not to lose market share to imported downstream products, either in raw material or final finished product imports, Mittal offers rebates to such firms that face this type of competition. Heavy equipment manufacturers have received this rebate as an apparent response to the threat of potential imports from Australia, Germany and Sweden ${ }^{17}$. Conveyor manufacturers also receive rebates to enable them to compete against imports and alternative construction materials. Substantial rebates were granted to flange ${ }^{18}$ manufacturers as protection from cheaper Chinese imports.

\section{c. Special industry deals}

Another rebate class offered to certain customers is the special industry deal rebate. These are given to customers that have substantial buyer power and who use this power to negotiate with Mittal. These include the favourable rebates given to the packaging industry and the automotive industry.

One large firm in the packaging industry receives a special deal that is calculated using a cost plus basis formula for the tin plate that they procure from Mittal ${ }^{19}$. This formula sets the price level of the tinplated steel sold to the company and the price increases by taking into account a weighted basket of the world price of tin, the price of the input materials - gas at contract prices, iron ore and local coking coal price changes proxied by the producer price index (PPI), imported coking coal at the actual price, as well as salaries, electricity and other costs ${ }^{20}$. This price, in contrast to the IPP, is more representative of the costs of manufacturing tinplated steel. As such, it provides an idea of what a reasonably competitive price benchmark should be, and this price is considerably lower than the IPP facing most customers.

The automotive industry is another powerful buyer that is able to negotiate favourable deals with Mittal. The price that firms in this industry receive is based on an ex-works price in the EU and adjustments in local PPI. The industry association insisted that in order to achieve international price competitiveness in the 
automotive industry, Mittal would have to adopt another pricing mechanism and not use the existing IPP model. Industry representatives suggested that an ex-works basis was internationally more competitive given that it is a cost-driven figure ${ }^{21}$. Mittal recognises that if prices in this industry were too high, manufacturers of cars would relocate their production capacity entirely or resort to importing components or full vehicles rather than using local steel. The price received by the automotive industry is therefore not based on the IPP mechanism but is one in which low underlying cost pressures reflected in the PPI are passed on to the benefit of steel buyers. Industries that did not qualify for this special deal paid substantially higher prices than the price given to the automotive industry between 2004 and 2005 for the same product.

d. Rebates in the face of threat of substitute products

Another comparator used by the complainants was the price given to firms to enable them to compete with substitute products such as aluminium, plastic, cement and timber. Prices to customers that could potentially switch to these products showed the level prices tended to when there was some form of competition from alternative products. For instance, aluminium cans, plastic or glass bottles for the food and beverage industry could be used instead of steel cans, cement or clay instead of steel roof tiles, timber trusses instead of steel trusses. Mittal accepts that such products affect their market and that it takes into account the prices of these potential substitute products available for use in certain industries when pricing its steel.

e. Mittal's export price of flat steel products

Mittal directly exports its products through an exclusive agreement via a joint venture with Macsteel International BV, a listed company in the Netherlands. Part of this agreement stipulates that the product exported cannot be re-imported and sold into the domestic market, in effect meaning that exports can be a means of reducing supply to the local market. Export prices of products have been substantially lower than local prices, sometimes up to sixty per cent ${ }^{22}$. As explained above, prices in an open economy under effective competition should tend towards the export price. If effective local competition drives the local price lower than the export price, producers would choose to export the product rather than to sell it to the local market. This export price would then be a good benchmark on which the economic value of a product could be determined in a net-exporting country.

However, for export prices to be a useful benchmark for competition, these prices have to adequately cover the firm's costs of production and yield sustainable returns in the long run. This case raised two important concerns in this regard. First, in cyclical industries such as the global steel industry achievable prices for exports may well cover costs and offer sustainable returns at the peak of the cycle but not necessarily over the whole cycle. Therefore, it is important in such industries to understand the dynamics of the global market and to compare export prices over a longer period of time that adequately covers a given cycle.

While Mittal argued that the steel prices in 2005 and 2006 represented a peak from which they would soon fall, evidence on the decisions made to expand production by Mittal seemed to suggest that it expected global prices to be attractive in the near future. Mittal exports around forty per cent of its product. It planned to increase its capacity to produce even more steel, of which much, if not all, would be exported given that supply already outstrips local demand. Therefore, such expansion plans are based predominantly on export prices that will be realised by the sale of the output of the additional new capacity to the export market. Such extensive expansion plans based on export prices achievable would not rationally be made if these export prices did not cover costs and did not yield sustainable returns. Moreover, as was revealed in the course of the hearings, even on a pessimistic 
outlook, export prices were expected to yield positive returns on investment. Export prices for flat steel product from Vanderbijlpark, according to figures put up by Mittal's own experts and adjusted to take into account differences in product mix and other additional considerations (such as higher export price countries due to anti-dumping restrictions), show that these prices more than adequately cover costs and do so by a large margin.

While the export price can be a useful benchmark in a net exporting country, the actual price charged in the local market should also take into account any costs for relevant quality and dimension extras. In certain industries, such as the steel industry, exported product is often more basic and with less value addition than product sold locally.

An additional important consideration when identifying benchmarks for competition, or when undertaking a price cost analysis, is whether the firm in question (or a competing firm whose pricing is identified as an appropriate benchmark) is an efficient firm. Costs of inefficient firms are likely to be inflated, masking the true margins. Although Mittal enjoys low production costs, this does not automatically mean that it is an efficient firm. The fact that it faces low production costs is due to the favourable input material costs that Mittal receives and not particularly because of high levels of productivity, innovation and efficiency that serve to reduce operating costs. Therefore, although Mittal may be in the lowest cost quartile of international steel plants, this reflects its lucky position in a country blessed with abundant and low cost material inputs into which Mittal is either backwardly integrated, or in which it has received preferential rates through long-term supply agreements.

Further, Mittal's annual reports and presentations reveal the efficiencies gained between 2001 and 2005. These include savings made under the Business Assistance Agreement (BAA) and amount cumulatively to around R1 billion per year. Mittal itself recognises that it was hugely inefficient in the past as it tried to cater for all its customers' unique needs and produced around 500 different grades of steel at Vanderbijlpark. This was later reduced to 120 grades following a rationalisation programme which resulted in major cost savings ${ }^{23}$. Largescale retrenchments (around 10000 workers) were also undertaken as a drive to improve efficiency ${ }^{24}$. While it does not necessarily follow that embarking on these efficiencies now means that Mittal was inefficient in the past, what is notable is the magnitude of the cost savings achieved in a short space of time as well as the fact that none of these savings are from new state-of-the-art technological advances. In other words, such efficiencies and cost savings could have been achieved years ago.

Even though innovation can be seen broadly to include new ways of marketing a product, new methods of production, new sources of supply of raw materials, or process innovations, as proposed by Schumpeter (1934), improved management as part of restructuring a former state-owned industry is not innovation. In this regard, it appears as if the cost savings made at Mittal Steel SA, planned and already implemented, were basic improvements that could have been achieved by Iscor even before Mittal acquired $i^{25}$. This suggests that these improvements in efficiency may have been a result of incentivised management under private ownership and not as a result of any process innovations.

\section{Summary}

The above comparators reveal the conduct of Mittal in terms of unilateral price-setting and market segmentation consistent with the unilateral exertion of market power. They also illustrate where greater competitive discipline exists, whether directly or indirectly, Mittal responds in its pricing but prevents its overall pricing on the majority of its product being undermined. The majority of customers paid prices set at import parity levels. The comparators thus also allow for assessments of anti-competitive effect in that they provide situations where the counterfactual of prices under effective competitive rivalry can be considered.

It is important to note that such discriminatory pricing practices can only be sustained if 
arbitrage can explicitly be prevented between the different price groups. Mittal has in place checks and balances that serve to monitor very strictly that arbitrage between the different customer groups or designated uses of the product do not take place.

It may be argued that the different prices may just reflect consumers' willingness to pay. However, this merely goes to the essence of the monopoly pricing decision, taking into account the nature of demand and, in this case, imperfect alternatives in the form of imported steel. Higher prices in South Africa may also be argued just to reflect higher production costs than in other countries but we have shown that this was not the case here. In addition, there is no guarantee that comparing the dominant firm's prices with a competitor's prices will provide an objective idea of what a competitive price should be; the competitor's price itself may be excessive or predatory (Evans \& Padilla, 2005: 109). Lastly, for a comparator to be a benchmark for competitive prices, it has to represent an outcome that is sustainable. This relates to the issue of the efficiency of the firm in question, which I address in more detail in the following section.

\subsection{Is there a role for a profitability analysis in an excessive pricing case?}

Evaluating whether prices are excessive could be equated with evaluating whether profits are excessive. For example, according to the UK's OFT, "the ability of an undertaking...to earn excessive profits may provide evidence that it possesses some degree of market power" (OFT, 1999: 7). The level of profitability could therefore be another test used to assess the extent of excessive pricing and indeed an important part of Mittal's defence rested on such a profitability analysis. This section looks at the use of a profitability analysis and argues that there are substantial pitfalls in using this as a measure of excessive pricing.

At the outset it is important to remember that our task is to evaluate conduct while profitability is an accounting measure of performance. Using accounting measures in general could however be problematic given that there are a number of interpretations of which measures to use. Indeed, as Lind and Walker (2003: 1) observe, "measuring profitability in an economically meaningful way is virtually impossible to do for any complex business." While measures include internal rate of return (IRR) and net present value (NPV) these generally use data represented by a firm for accounting purposes, raising various problems including the valuation of assets. A firm may value assets based on historical costs of capital. But for firms that purchased their assets a long time ago and were in a high inflationary environment, the value of their assets reported may be very low, making their profitability (profits divided by assets employed) appear excessively high. A firm may argue that it should price in order to cover the replacement cost of assets yet the investments may have been made by the state and in any event would never be repeated in this form ${ }^{26}$.

In industries such as fixed-line telecommunications with large sunk costs, regulators engage in detailed exercises to assess pricing in relation to long-run incremental costs to reflect the costs of expanding capacity. In the case of the steel industry, experts who compare costs of steel plants globally calculate a "sustaining capital expense", which is the actual average annual capital expenditure needed to maintain the plant at a constant condition in the long run. For Mittal this was much lower than the replacement cost of the whole plant ${ }^{27}$.

For profitability to be indicative of anticompetitive conduct one must also assume that the firm is otherwise being run efficiently and that the profits are not due returns for innovative activities, as discussed above. A firm that is run inefficiently is likely to have inflated costs and therefore its profit margins would be squeezed. Principal-agent theory suggests this is possible where, in a monopoly situation, weak shareholder monitoring of management allows management to engage in satisficing behaviour. Conversely, vigorous competitive rivalry stimulates management effort and greater productive efficiency. Other problems with this method of analysis include accounting for the cyclical nature of some industries, such as the steel industry. 
Given the numerous problems related to the use of appropriate accounting measures, the use of profitability as the main test in assessing excessive pricing is generally discouraged. It involves competition authorities engaging in very detailed evaluations of accounting data, something they are not generally well-equipped to do. However, profitability can provide useful insights as part of the overall picture if due attention is paid to the various factors we have identified.

\section{4 \\ Some conclusions}

Excessive pricing is, by definition, about understanding a particular conduct. The structure that allows the conduct is clearly a crucial part of the assessment and may indeed be illuminated by the conduct itself. In the case discussed here, there are high and non-transitory barriers to entry that collectively serve to limit competition in the South African flat steel industry, and this was reinforced by the various ways in which Mittal engaged in unilateral pricesetting of its products. The structural conditions thus facilitate the abuse as they provide for durable or sustained market power, but they are not sufficient to conclude that a dominant firm has engaged in excessive pricing. It is very important to assess conduct that represents a unilateral abuse of market power in terms of the nature of the industry and markets in question, as well as how the firm came to be in such a position of dominance.

Dominant firms are prevalent in many other industries in South Africa, given its small size, legacy of apartheid and previous strong state ownership and support. There are significant barriers that limit the contestability of markets and result in super-dominant firms being able to mark up prices substantially above a level that is deemed competitive and reflective of economic value.

The Tribunal, in ruling that Mittal had abused its dominance, strongly emphasised the incontestable and uncontested nature of the market, with conduct not being subject to the constraining presence of a regulator or of a potential entrant. Indeed, according to the Tribunal, section 8(a) uniquely applies to such industries where firms can be characterised as "super-dominant". As stated in the ruling, "it is conduct that abuses a structural advantage - dominance or, in Section 8(a)'s case, 'superdominance' - that is prohibited"28.

This broadly follows the suggested structural conditions. Given this interpretation, the Tribunal found that Mittal was indeed a super-dominant firm. It operated in an incontestable market with entry barriers that were established by historical circumstances as well as technological and commercial considerations which have had as great an impact as barriers constituted by law or license ${ }^{29}$. The Tribunal further found that the essential ancillary conduct that flowed out of this super-dominant structure was to withhold local supply ${ }^{30}$, facilitated by the exclusive export arrangement with Macsteel that allowed the segmenting of the domestic and export markets. While segmentation within the local market through the various rebates discussed in the complainants' comparators approach was also considered by the Tribunal, it was made clear that the purpose of such consideration was strictly not to arrive at a level of price that would be lawful or non-excessive compared to an identified unlawful or excessive price ${ }^{31}$. This would be more the role of a price regulator and not one which a competition authority would seek to undertake.

Therefore the Tribunal's test of excessive pricing is summarised as follows:

[W] here the price appears to have no explanation other than the pure exercise of monopoly power [as evidenced by the structure of the market and any relevant ancillary conduct on the part of the dominant firm], then the price is not reasonable in relation to economic value ${ }^{32}$

Since the Tribunal's interpretation would involve an examination of the underlying market considerations that lead to the price level (rather than the price level itself), the risk of penalising firms that charge high prices due to extensive innovation and differentiation is reduced ${ }^{33}$. In this case it was clear that the flat steel product market was not one such dynamic 
market that was characterised by innovation and investment ${ }^{34}$.

The Tribunal's decision provides the precedent for interpreting Section 8(a) and forms a sound conceptual basis upon which new excessive pricing cases can be analysed. However, it may be argued that the Tribunal's approach alone may be too narrow and may risk more type 2 errors/false acquittals given the high standards required to qualify as a firm that could contravene the excessive pricing provision in the Act.

While the Tribunal's approach is a good starting point, a convergence of evidence through a multi-facetted approach may be a better practice in dealing with excessive pricing complaints. This would involve engaging further in assessments of conduct of the firm as described in this paper, including price-setting behaviour under conditions of effective competition and evaluating underlying cost structures. Establishing some idea of a competitive benchmark would also then assist the authorities in arriving at appropriate remedies.

\section{Endnotes}

1 This article draws from the research undertaken for the complaint against Mittal Steel SA by author, Simon Roberts and Ryan Hawthorne. It does not necessarily reflect the views of my fellow researchers or the Competition Commission.

2 Case No. 13/CR/Feb04, Harmony Gold Mining co ltd, Durban Roodepoort Deep Limited and Iscor Ltd, Mac Steel International BV.

3 The Competition Tribunal of South Africa, in the matter between Harmony Gold Mining Co Ltd, Durban Roodepoort Deep Limited and Iscor Ltd, Mac Steel International BV; Case No. 13/CR/ Feb04, Reasons. 27th March 2007, para 142.

4 Testimony of Rustomjee, p 770-785, nonconfidential transcript.

5 http://www.saisi.co.za/localsales.php, accessed on 19/02/08.

6 According to the complainants' analysis as presented to the Tribunal.

7 Adv. Unterhalter, p19, non-confidential transcript.

8 Tomlinson cross examination at p 2365, p 2366, p 2375, non-confidential transcript.

9 Investor relations presentation, available on www. iscor.co.za.
10 Slide 33 of the Annual results for the 12 months ended December 2004; Saldanha's operating cost was 247 US\$/t, while Vanderbijlpark's was 256 US $\$ / t$ - both levels which fell within the lowest decile of international operating costs.

11 Roberts's testimony p1092, 1093, non-confidential transcript.

12 http://www.saisi.co.za/localsales.php and http:// www.saisi.co.za/exports.php, accessed on 19/02/08.

13 Typical common costs include equipment cost, salaries, legal and audit expenses.

14 Attheraces Limited v. The British Horseracing Board Limited (Case No A3/2006/0126).

15 In 2004, Mittal's average domestic price in 2004 was $\$ 572$ per tonne for HRC. In the same year, China's price was $\$ 434$, Germany's price was $\$ 550$, South Korea's \$419, Taiwan's \$450 and Brazil's $\$ 481$. In 2005, Mittal's average price of $\$ 617$ per tonne was higher than China's $\$ 419$, South Korea's \$581, Taiwan's \$492 and Germany's \$583.

16 The comparators' method was used in the famous United Brands case (United Brands Company v EC Commission 27/76 [1978] ECR 207,) as well as the more recent NAPP pharmaceuticals matter (Pharmaceutical Holdings Ltd v Director General (Case No Ca98/2/2001), both excessive pricing complaints.

17 Bell evidence in chief p 312 and p 326, nonconfidential transcript.

18 A flange is an external or internal rib or rim, used either to add strength or to hold something in place.

19 Lang evidence in chief p 229 to 230, nonconfidential transcript.

20 Lang evidence, p 297, non-confidential transcript.

21 Evidence by automotive industry players.

22 Adv Unterhalter, p 2364, non-confidential transcript, 29 Nov 06.

23 Dednam evidence in chief at p1671 to 1672 , nonconfidential transcript.

24 Mittal intends reducing its cash costs by 22 per cent between 2005 and 2007 simply by expanding output by one million tonnes per annum. It also continues to engage in on-going capital expenditure projects (Schoeman evidence in chief at $\mathrm{p} 1008$ to 1009 , non-confidential transcript).

25 Schoeman cross-examination at 1018, 1039 to 1041, 1044, 1046, 1052 to 1055.

26 In the Helsingborg decision, Scandlines Sverige $A B$ v Port of Helsingborg (Case No COMP/ A.36.568/D3) the European Commission found that the cost breakdown put forth by the respondent in their profitability analysis was unreasonable. Such costs could not feasibly be 
the costs incurred by Helsinborg to provide facilities and services to ferry operators and other port users. If they were, Helsinborg would face bankruptcy, which was not reflected in its audited financial statements. The use of replacement costs of capital indeed seemed unreasonable in this case. One would not expect depreciation to be calculated based on the assumption that the entire port would be replaced each year.

27 Tomlinson evidence, p1497-1499.

28 P 49, para 133 of Tribunal's reasons.

29 P 37, para 105 of Tribunal's decision.

30 Para 164 of Tribunal's decision.

31 Para 134 of Tribunal's decision.

32 Paras 147, 151 of Tribunal's decision.

33 Para 151 of Tribunal's decision.

34 Para 102 of Tribunal's decision.

\section{References}

1 COMPETITION TRIBUNAL OF SOUTH AFRICA (2007) Reasons in the matter between Harmony Gold Mining co ltd, Durban Roodepoort Deep Limited and Iscor Ltd, Mac Steel International BV; Case No. 13/CR/Feb04, 27th March 2007.

2 EVANS, D. \& PADILLA, J. (2005) "Excessive prices: Using economics to define administrable legal rules", Journal of Competition Law and Economics, 1(1): 97-122.

3 FINGLETON, J. (2006) "De-monopolizing Ireland", European Competition Law Annual: 2003, in C. Ehlermann \& I. Antanasiu (eds.) What is an Abuse of a Dominant position? Hart Publishing: Portland, Oregon, USA: 53-68.

4 GAL, M. (2004) Monopoly Pricing as an Antitrust Offence in the U.S. and the EC: Two Systems of Belief about Monopoly? Federal Legal Publications, Inc.: 390A Heritage Hills, NY 10589.

5 LEACH, D.F. (1992) "Concentration and profits in South Africa: Monopoly or efficiency?" The South African Journal of Economics, 60(2): 143-157.
6 LIND, R. \& WALKER, M. (2003) “The mis(use) of profitability analysis in competition law cases", Charles River Associates Competition Policy, discussion paper 9 .

7 MARTIN, S. (1993) Industrial EconomicsEconomic Analysis and Public Policy (2 ${ }^{\text {nd }}$ ed.) Prentice Hall: Upper Saddle River, N.J.

8 MONTI, M. (2006) "Panel discussion (panel one)Policy objectives, enforcement tools and actors, types of abuses, the case of excessive pricing", in European Competition Law Annual: 2003, What is an Abuse of a Dominant Position? C. Ehlermann \& I. Antanasiu (eds.) Hart Publishing: Portland, Oregon, USA: 3-50.

9 MOTTA, M. \& DE STREEL, A. (2006) "Excessive pricing and price squeeze under EU law", in European Competition Law Annual: 2003, What is an Abuse of a Dominant Position? C. Ehlermann \& I.Antanasiu (eds.) Hart Publishing: Portland, Oregon, USA: 91-125.

10 OFFICE OF FAIR TRADING (1999) "Assessment of individual agreements and conduct", Report no: 414.

11 OFFICE OF FAIR TRADING (2003) "Assessing profitability in competition policy analysis", Economic Discussion Paper 6, report prepared for the Office of Fair Trading by OXERA, Report no: 657.

12 REEKIE, W.D. (1999) "The Competition Act 1998: An economic perspective", The South African Journal of Economics, 67(2): 257-288.

13 SCHUMPETER, J.A. (1934) The Theory of Economic Development: An Inquiry into Profits, Capital, Credit, Interest, and the Business Cycle, Harvard University Press: Cambridge, MA.

14 THERON, N. (2001) "The economics of competition policy: Merger analysis in South Africa", South African Journal of Economics, 69(4): 614-658.

15 WHISH, R. (2003) Competition Law (5 ${ }^{\text {th }}$ ed.) Lexis Nexis: London. 